Material Properties

\title{
Imidazolium ionic liquids as fracture toughening agents in DGEBA-TETA epoxy resin
}

\author{
E. Fonseca ${ }^{a}$, V. Demétrio da Silva ${ }^{\text {a,b, }}$, J.S. Klitzke ${ }^{\mathrm{b}}$, H.S. Schrekker ${ }^{\mathrm{b}}$, S.C. Amico $^{\mathrm{a}}$ \\ ${ }^{a}$ PPGE3M, Federal University of Rio Grande do Sul - UFRGS, Av. Bento Gonçalves 9500, Porto Alegre, RS, 91501-970, Brazil \\ ${ }^{\mathrm{b}}$ Laboratory of Technological Processes and Catalysis, Institute of Chemistry, Federal University of Rio Grande do Sul - UFRGS, Av. Bento Gonçalves 9500, Porto Alegre, \\ RS, 91501-970, Brazil
}

\section{A R T I C L E I N F O}

\section{Keywords:}

Crosslink density

Imidazolium salt

Bisphenol A

Curing agent

\begin{abstract}
A B S T R A C T
Although epoxy resins are used in a broad variety of applications due to their good mechanical and thermal properties, their low fracture toughness is a limitation, exhibiting brittle behavior. This study explored the potential use of imidazolium ionic liquids (IL) as toughening agents for epoxy resin based on diglycidyl ether of bisphenol A (DGEBA) with triethylenetetramine (TETA) as curing agent. Fracture toughness was evaluated for DGEBA-TETA epoxy resins with eleven imidazolium IL and the best results were found for the IL with the chloride anion and the shortest $\mathrm{N}$-alkyl side chain, $\mathbf{C}_{4} \mathbf{M I m C l}$. The use of $1.0 \mathrm{phr}$ of $\mathbf{C}_{4} \mathbf{M I m C l}$ lead to the reduction of the crosslink density of the post-cured resin, resulting in the increase of $25.5 \%$ in stress intensity factor and $8.2 \%$ in tensile strength with no significant loss in other mechanical properties.
\end{abstract}

\section{Introduction}

Diglycidyl ether of bisphenol A (DGEBA)-based resins, widely used as polymer matrices for high-performance composite materials, form dense three-dimensional networks after curing (Fig. 1), leading to excellent mechanical properties and low thermal shrinkage. This also brings low fracture toughness and low impact strength, with a characteristic brittle fracture.

Several additives have been used to increase toughness, such as elastomers [1,2], solid nanoparticles [3-5] and thermoplastic polymers $[6,7]$. Nevertheless, many additives are insoluble solids that are difficult to disperse and increase resin viscosity, with a detrimental effect on composite manufacturing processes like those of the liquid molding type. Thus, liquid or soluble additives are preferred $[8,9]$.

Ionic liquids (IL) are organic salts that have a maximum melting point of $100{ }^{\circ} \mathrm{C}$, and many of them are liquid at room temperature [10-12]. IL such as 1-n-butyl-3-methylimidazolium tetrafluoroborate and 1-ethyl-3-methylimidazolium dicyanamide are latent curing agents for epoxy, and their reactivity as curing agents has been related to their thermal decomposition temperatures $[13,14]$.

Imidazolium IL can attack the $-\mathrm{CH}_{2}-$ unit of an oxirane ring in DGEBA following three possible mechanisms, as depicted in Fig. 2 for 1n-butyl-3-methylimidazolium chloride [15]: (i) nucleophilic attack of the anion over a wide range of temperatures, depending on its reactivity. At the same time, the imidazolium cation can activate the oxirane for a nucleophilic attack by the anion through hydrogen bonding (imidazolium $\mathrm{C} 2-\mathrm{H}$... O oxirane); (ii) deprotonation of the imidazolium ring at ca. $60{ }^{\circ} \mathrm{C}$ to form a $\mathrm{N}$-heterocyclic carbene, and subsequent reaction with an epoxy group; (iii) dealkylation of the imidazolium ring at ca. $90{ }^{\circ} \mathrm{C}$, which is more prominent at higher IL contents, and subsequent reaction with an epoxy group. In mechanisms (i) and (ii), the imidazolium IL will result in branches (see A), and only in the case of mechanism (iii) it can be directly involved in DGEBA crosslinking. Altogether, this illustrates the complexity of these IL-cured epoxy resin systems.

IL can participate in curing reactions of epoxy resins in an even more complex way in the presence of a traditional curing agent, as reported by several authors. Guo et al. [16] observed an increase in activation energy for higher conversion rates of the DGEBA/Jeffamine ${ }^{\circledR}$ mixture containing 1-n-butyl-3-methyl-imidazolium hexafluorophosphate, attributed to hydrogen bond formation between Jeffamine ${ }^{\circledR}$ and IL. For an aromatic curing agent, Soares et al. [17] and Shi et al. [18] achieved an increase in storage modulus below the glass transition temperature $\left(\mathrm{T}_{\mathrm{g}}\right)$ with an imidazolium IL. The higher curing temperatures used for aromatic curing agents contributed to the formation of a more densely crosslinked polymer. A decrease in $\mathrm{T}_{\mathrm{g}}$ of DGEBA-based epoxy resins was also observed, suggesting a plasticizer effect due to the presence of

\footnotetext{
* Corresponding author. PPGE3M, Federal University of Rio Grande do Sul - UFRGS, Av. Bento Gonçalves 9500, Porto Alegre, RS, 91501-970, Brazil.

E-mail address: demetrio@ufrgs.br (V. Demétrio da Silva).
} 


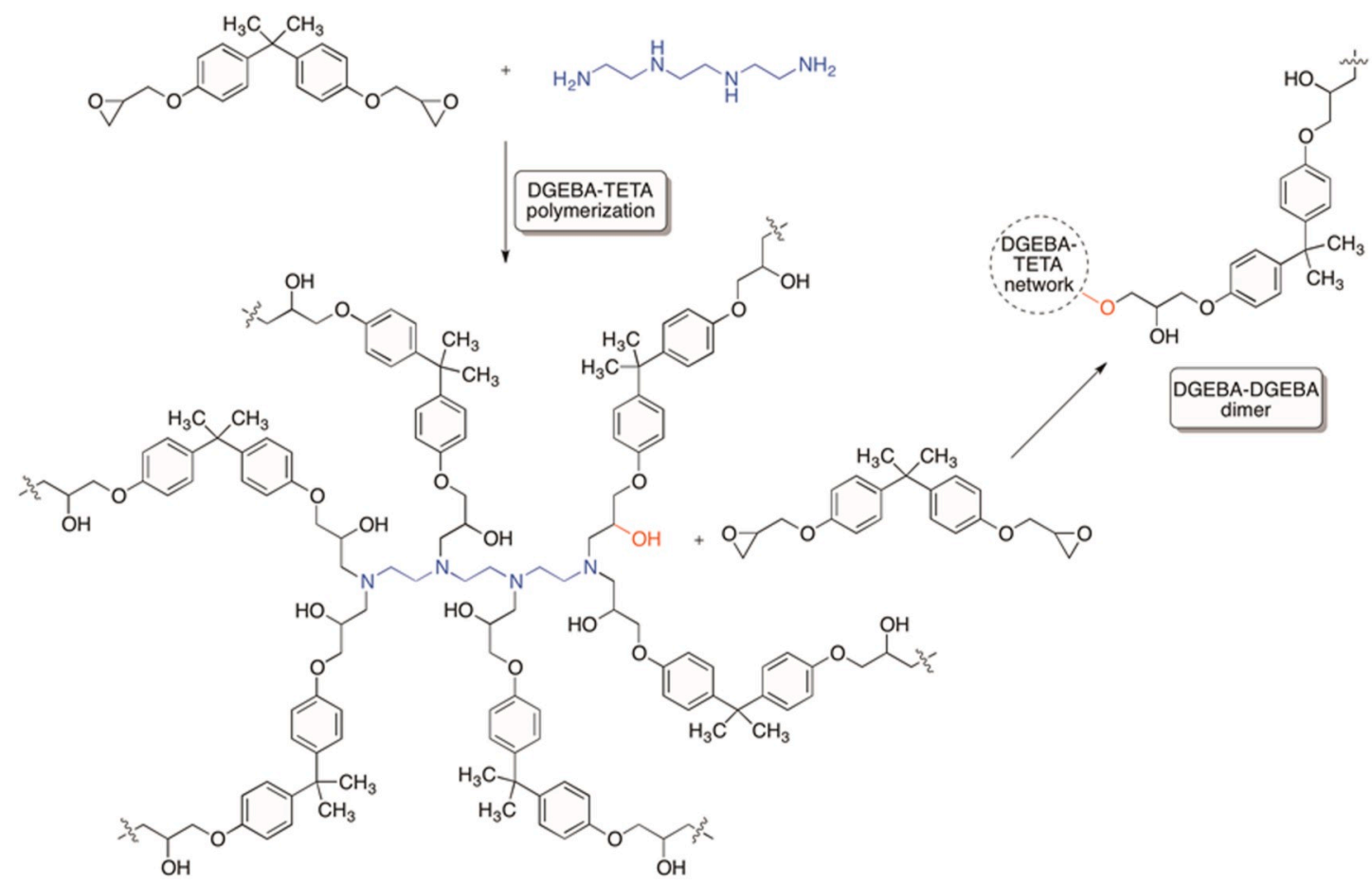

Fig. 1. Representation of the formation of a three-dimensional network between DGEBA and triethylenetetramine (TETA), and DGEBA dimerization within the DGEBA-TETA network.

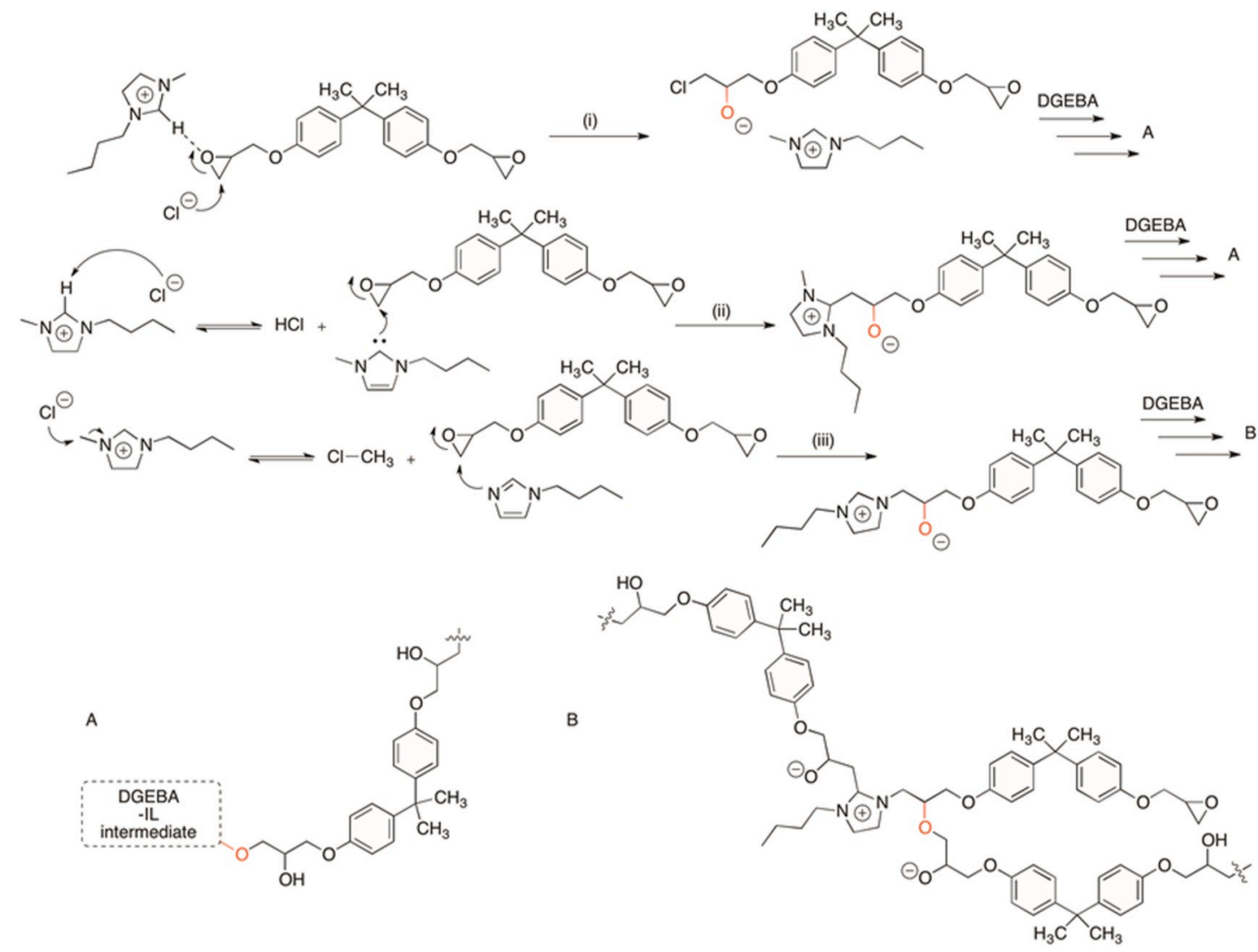

Fig. 2. 1-n-Butyl-3-methylimidazolium chloride and DGEBA interaction through the mechanisms: (i) nucleophilic attack of the anion, (ii): $N$-heterocyclic carbene formation (network A); and (iii) dealkylation of the imidazolium ring (network B), i.e. as a crosslinking curing agent. 
Table 1

List of IL used in this work.

\begin{tabular}{|c|c|c|}
\hline Chemical structure & Nomenclature & Acronym \\
\hline $\mathrm{Cl}^{\ominus}$ & $\begin{array}{l}\text { 1-n-butyl-3- } \\
\text { methylimidazolium } \\
\text { chloride }\end{array}$ & $\mathrm{C}_{4} \mathrm{MImCl}$ \\
\hline & $\begin{array}{l}\text { 1-n-decyl-3- } \\
\text { methylimidazolium } \\
\text { chloride }\end{array}$ & $\mathrm{C}_{10} \mathrm{MImCl}$ \\
\hline & $\begin{array}{l}\text { 1-n-octadecyl-3- } \\
\text { methylimidazolium } \\
\text { chloride }\end{array}$ & $\mathrm{C}_{18} \mathrm{MImCl}$ \\
\hline & $\begin{array}{l}\text { 1- } n \text {-hexadecyl-2,3- } \\
\text { dimethylimidazolium } \\
\text { chloride }\end{array}$ & $\mathrm{C}_{16} \mathrm{M}_{2} \operatorname{ImCl}$ \\
\hline & $\begin{array}{l}\text { 1,3-di- } n \text {-hexadecyl- } \\
\text { imidazolium chloride }\end{array}$ & $\left(\mathrm{C}_{16}\right)_{2} \operatorname{ImCl}$ \\
\hline & $\begin{array}{l}\text { 1-carboxymethyl-3- } \\
\text { methylimidazolium } \\
\text { chloride }\end{array}$ & $\mathrm{HO}_{2} \mathrm{CC}_{1} \mathrm{MImCl}$ \\
\hline & $\begin{array}{l}\text { 1,3-dicarboxymethyl- } \\
\text { imidazolium chloride }\end{array}$ & $\left(\mathrm{HO}_{2} \mathrm{CC}_{1}\right)_{2} \operatorname{ImCl}$ \\
\hline & $\begin{array}{l}\text { 1- } n \text {-butyl-3- } \\
\text { methylimidazolium bis } \\
\text { (trifluoromethylsulfonyl) } \\
\text { imide }\end{array}$ & $\mathrm{C}_{4} \mathrm{MImNTf}_{2}$ \\
\hline & $\begin{array}{l}\text { 1-n-hexadecyl-3- } \\
\text { methylimidazolium } \\
\text { bromide }\end{array}$ & $\mathrm{C}_{16} \mathrm{MImBr}$ \\
\hline & $\begin{array}{l}\text { 1,3-di- } n \text {-hexadecyl- } \\
\text { imidazolium bromide }\end{array}$ & $\left(\mathrm{C}_{16}\right)_{2} \operatorname{ImBr}$ \\
\hline & $\begin{array}{l}\text { 1,3-di- } n \text {-hexadecyl- } \\
\text { imidazolium } \\
\text { methanesulfonate }\end{array}$ & $\left(\mathrm{C}_{16}\right)_{2} \mathrm{ImMeS}$ \\
\hline
\end{tabular}

excess IL. For an aliphatic curing agent, however, Soares et al. [19] obtained the opposite effect, that is, a decrease in storage modulus below $\mathrm{T}_{\mathrm{g}}$, making the material more ductile with the addition of IL.

Addition of IL to epoxy may also affect its fracture toughness. Nguyen et al. [20], using phosphonium-based IL, reported an inverse correlation between crosslink density and $\mathrm{K}_{\mathrm{IC}}$ (stress intensity factor). This way, the IL could be used as additive for the modification of physical and mechanical properties of epoxy resins. In this context, this work investigates the potential and novel use of imidazolium IL (Table 1), with different anions and imidazolium $N$-alkyl and -carboxyalkyl, and C2-substituents, as toughening agents for epoxy resin in the presence of a conventional, low temperature, aliphatic amine curing agent. Fracture toughness was evaluated based on stress intensity factor and critical strain energy release rate results and correlated to crosslink density.

\section{Experimental}

\subsection{Imidazolium salts}

1-n-Butyl-3-methylimidazolium chloride $\left(\mathrm{C}_{4} \mathrm{MImCl}\right)$, 1-n-decyl-3methylimidazolium chloride $\left(\mathrm{C}_{10} \mathrm{MImCl}\right)$ and 1-n-butyl-3-methylimidazolium bis (trifluoromethylsulfonyl) imide $\left(\mathbf{C}_{4} \mathbf{M I m N T f}_{2}\right)$ were obtained from Sigma-Aldrich. 1-Methyl-3-n-octadecylimidazolium chloride $\left(\mathrm{C}_{18} \mathbf{M I m C l}\right)$ was purchased at CJC China JIE Chemical. 1- $n$ Hexadecyl-3-methylimidazolium bromide $\left(\mathbf{C}_{16} \mathbf{M I m B r}\right.$; see Fig. S1 for the ${ }^{1} \mathrm{H}$ NMR spectrum) [21], 1-carboxymethyl-3-methylimidazolium chloride $\left(\mathrm{HO}_{2} \mathbf{C C}_{1} \mathbf{M I m C l}\right.$; see Fig. S2 for the ${ }^{1} \mathrm{H}$ NMR spectrum) [22], 1,3-di- $n$-hexadecylimidazolium chloride $\left(\left(\mathrm{C}_{16}\right)_{2} \mathrm{ImCl}\right.$; see Fig. S3 for the ${ }^{1} \mathrm{H}$ NMR spectrum) [23], 1,3-bis(carboxymethyl)imidazolium chloride $\left(\left(\mathrm{HO}_{2} \mathrm{CC}_{1}\right)_{2} \mathrm{ImCl}\right.$; see Fig. S4 for the ${ }^{1} \mathrm{H}$ NMR spectrum) [22], $n$-hexadecyl methanesulfonate ( $\mathbf{C}_{16} \mathbf{M e S}$; see Fig. S5 for the ${ }^{1} \mathrm{H}$ NMR spectrum) [24] and 1-n-hexadecylimidazole $\left(\mathbf{C}_{\mathbf{1 6}} \mathbf{I m}\right.$; see Fig. S6 for the ${ }^{1} \mathrm{H}$ NMR spectrum) [25] were synthesized according to the cited references, and the spectral data were in agreement with the reports.

The cited NMR spectra were recorded in a Bruker (400 MHz) equipment at room temperature. The chemical shifts are given in parts per million (ppm) and referenced to the residual solvent signal $\left(\mathrm{CDCl}_{3}=\right.$ $7.26\left({ }^{1} \mathrm{H}\right)$, $77.16\left({ }^{13} \mathrm{C}\right)$; DMSO- $\left.d_{6}=2.50\left({ }^{1} \mathrm{H}\right) ; \mathrm{D}_{2} \mathrm{O}=4.79\left({ }^{1} \mathrm{H}\right)\right)$. Attenuated total reflection Fourier transform infrared spectroscopy (ATR-FTIR), in the mid infrared range $\left(4000-500 \mathrm{~cm}^{-1}\right)$, was obtained in an ALPHA-P compact Bruker FTIR spectrometer. High-resolution mass spectrometry was performed in an electrospray ionization (ESI) Q-Tof Micro ${ }^{\mathrm{TM}}$ equipment (Micromass, Manchester, UK) in the positive mode.

A modified literature procedure was used for the synthesis of 1- $n$ hexadecyl-2,3-dimethylimidazolium chloride $\left(\mathbf{C}_{\mathbf{1 6}} \mathbf{M}_{\mathbf{2}} \mathbf{I m C l}\right)$ [26]. The mixture of $n$-hexadecyl chloride (21 mmol, 1.05 equiv.), 1,2-dimethylimidazole ( $20 \mathrm{mmol}, 1.00$ equiv.) and acetonitrile ( $3 \mathrm{~mL}$ ) was stirred and heated at $78^{\circ} \mathrm{C}$ for $42 \mathrm{~h}$. Next, the crude product was washed five times with a 1:1 mixture of acetonitrile:diethyl ether. After solvent removal under reduced pressure, $\mathrm{C}_{16} \mathbf{M}_{2} \mathrm{ImCl}$ was obtained in $84 \%$ yield as a white solid. See Fig. S7 for the ${ }^{1} \mathrm{H}$ NMR spectrum. ${ }^{1} \mathrm{H}$ NMR $(400 \mathrm{MHz}$, $\left.\mathrm{CDCl}_{3}\right) \delta 7.80(\mathrm{~d}, J=2.0 \mathrm{~Hz}, 1 \mathrm{H}), 7.44(\mathrm{~d}, J=2.0 \mathrm{~Hz}, 1 \mathrm{H}), 4.17(\mathrm{t}, J=$ $7.5 \mathrm{~Hz}, 2 \mathrm{H}), 4.03(\mathrm{~s}, 3 \mathrm{H}), 2.78(\mathrm{~s}, 3 \mathrm{H}), 1.84-1.73(\mathrm{~m}, 2 \mathrm{H}), 1.34-1.18(\mathrm{~m}$, $26 \mathrm{H}), 0.85(\mathrm{t}, J=6.8 \mathrm{~Hz}, 3 \mathrm{H})$. See Fig. S8 for the ${ }^{13} \mathrm{C}$ NMR spectrum. ${ }^{13} \mathrm{C}$ NMR (101 MHz, $\left.\mathrm{CDCl}_{3}\right) \delta 143.57,123.22,120.91,48.76,35.88,31.86$, 29.94-29.02 (11C), 26.37, 22.63, 14.07, 10.39. See Fig. S9 for the ATR-FTIR transmittance spectrum. MS-ESI $(+): \mathrm{C}_{21} \mathrm{H}_{41} \mathrm{~N}_{2}^{+}$- calculated: 321.3264, obtained: 321.0663 .

A modified literature procedure was used for the synthesis of 1,3-di$n$-Hexadecyl-imidazolium methanesulfonate $\left(\left(\mathrm{C}_{16}\right)_{2} \mathrm{ImMeS}\right)$ [26]. The mixture of $n$-hexadecyl methanesulfonate $\left(\mathbf{C}_{16} \mathbf{M e S}\right)$ (3.42 mmol, 1.00 equiv.) and 1 - $n$-hexadecylimidazole $\left(\mathbf{C}_{16} \mathbf{I m}\right)$ ( $3.42 \mathrm{mmol}, 1.00$ equiv.) was stirred and heated at $90{ }^{\circ} \mathrm{C}$ for $24 \mathrm{~h}$. Next, the crude product was recrystallized from ethyl acetate, obtaining $\left(\mathrm{C}_{16}\right)_{2} \mathrm{ImMeS}$ in $81 \%$ yield as white crystals. See Fig. S10 for the ${ }^{1} \mathrm{H}$ NMR spectrum. ${ }^{1} \mathrm{H}$ NMR (400 $\left.\mathrm{MHz}, \mathrm{CDCl}_{3}\right) \delta 10.08(\mathrm{t}, J=1.5 \mathrm{~Hz}, 1 \mathrm{H}), 7.24\left(\mathrm{~d},{ }^{3} J=1.5 \mathrm{~Hz}, 2 \mathrm{H}\right), 4.29$ $\left(\mathrm{t},{ }^{3} J=7.4 \mathrm{~Hz}, 4 \mathrm{H}\right), 2.79$ (s, 3H), 1.87 (m, 4H), 1.31-1.23 (m, 52H), 0.86 (t, $\left.{ }^{3} J=6.9 \mathrm{~Hz}, 6 \mathrm{H}\right)$. See Fig. S11 for the ${ }^{13} \mathrm{C}$ NMR spectrum. ${ }^{13} \mathrm{C}$ NMR (101 MHz, $\mathrm{CDCl}_{3}$ ) $\delta 138.17,121.37$ (2C), 50.06 (2C), 39.55, 31.90 (2C), 30.22 (2C), 29.83-29.24 (18C), 28.99 (2C), 26.23 (2C), 22.67 (2C), 14.11 (2C). See Fig. S12 for the ATR-FTIR transmittance spectrum. MS-ESI(+): $\mathrm{C}_{35} \mathrm{H}_{69} \mathrm{~N}_{2}^{+}$- calculated: 517.5455, obtained: 517.6363 .

\subsection{Preparation and characterization of DGEBA-TETA epoxy resin samples}

The IL was mixed with the diglycidyl ether of bisphenol A epoxy resin (DGEBA; Araldite ${ }^{\circledR}$ GY260, Huntsman) by sonication at $50^{\circ} \mathrm{C}$ for 
(a)

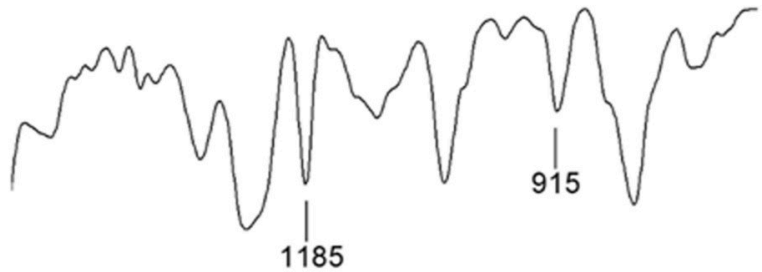

(b)

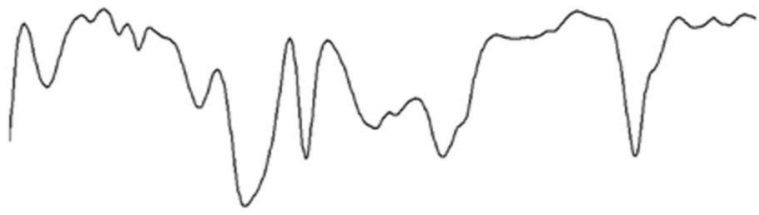

(c)
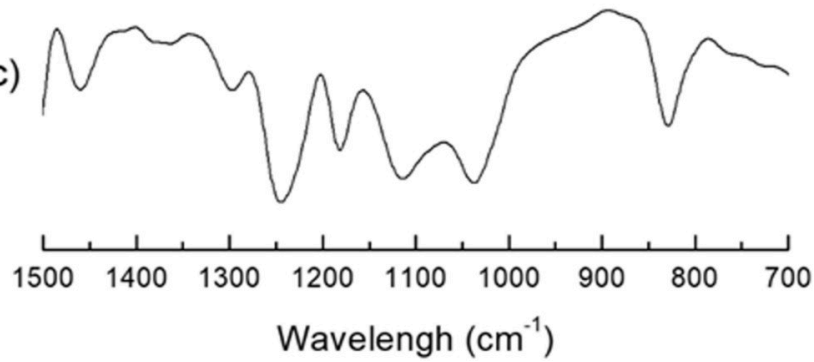

Fig. 3. FTIR transmission spectra of freshly mixed DGEBA/TETA (a), DGEBA/ TETA after post-curing (b), and DGEBA/TETA $+4.0 \mathrm{phr} \mathrm{C}_{4} \mathrm{MImCl}$ after postcuring (c).

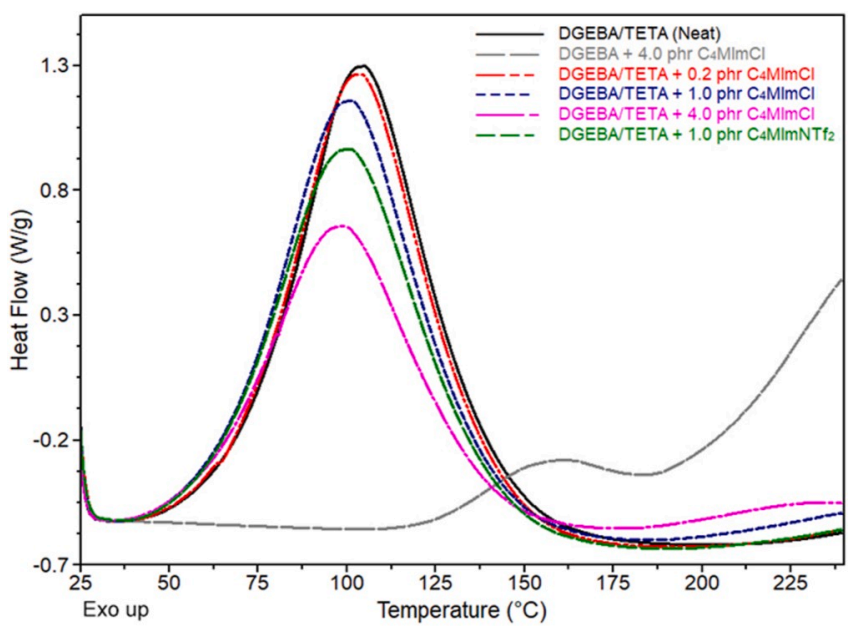

Fig. 4. DSC curves for DGEBA/TETA (neat), DGEBA with $\mathrm{C}_{4} \mathrm{MImCl}$, and DGEBA/TETA with $\mathbf{C}_{4} \mathbf{M I m C l}$ or $\mathbf{C}_{4} \mathrm{MImNTf}_{2}$.

30 min and triethylenetetramine (TETA; Aradur ${ }^{\circledR}$ 951, Huntsman) was added (13.0 phr), followed by magnetic stirring for $5 \mathrm{~min}$. All compositions were cured in a silicone mold at room temperature for $24 \mathrm{~h}$, then demolded and subjected to post-curing for $3 \mathrm{~h}$ at $100{ }^{\circ} \mathrm{C}$. Another DGEBA/TETA composition was prepared following the same protocol, but without IL, for comparison.

Fourier-transform infrared spectroscopy (FTIR) was carried out in a PerkinElmer Spectrum 1000 spectrometer, studying DGEBA-TETA before and after curing, and the composition with $4.0 \mathrm{phr}$ of $\mathrm{C}_{4} \mathbf{M I m C l}$ after curing. The liquid DGEBA-TETA was dropped on a $\mathrm{KBr}$ pellet. The cured samples were grounded and mixed with $\mathrm{KBr}$ to produce pellets. The $915 \mathrm{~cm}^{-1}$ band related to the $\mathrm{C}-\mathrm{O}$ stretching of oxirane groups was used to evaluate the degree of conversion (X (\%)) of epoxy groups (Eq. (1) [27]), with the $1183 \mathrm{~cm}^{-1}$ band related to the C-O group of the ether linkage as reference, since it remains unaltered during curing.
Table 2

Total reaction energy $\left(\Delta \mathrm{H}_{\mathrm{T}}\right)$, curing onset temperature $\left(\mathrm{T}_{\text {onset }}\right)$, temperature at maximum curing rate $\left(\mathrm{T}_{\max }\right)$, glass transition temperature $\left(\mathrm{T}_{\mathrm{g}}\right)$, storage modulus at $25{ }^{\circ} \mathrm{C}\left(\mathrm{E}^{\prime}\right)$ and crosslink density ( $v$ ) for DGEBA/TETA compositions with $\mathrm{C}_{4} \mathrm{MImCl}$ or $\mathrm{C}_{4} \mathrm{MImNTf}_{2}$; and $\mathrm{T}_{\text {onset }}$ for DGEBA with $4.0 \mathrm{phr}$ of $\mathrm{C}_{4} \mathrm{MImCl}$.

\begin{tabular}{lllllll}
\hline IL (phr) & $\begin{array}{l}\Delta \mathrm{H}_{\mathrm{T}} \\
(\mathrm{J} / \mathrm{g})^{\mathrm{a}}\end{array}$ & $\begin{array}{l}\mathrm{T}_{\text {onset }} \\
\left({ }^{\circ} \mathrm{C}\right)^{\mathrm{a}}\end{array}$ & $\begin{array}{l}\mathrm{T}_{\max } \\
\left({ }^{\circ} \mathrm{C}\right)^{\mathrm{a}}\end{array}$ & $\begin{array}{l}\mathrm{T}_{\mathrm{g}} \\
\left({ }^{\circ} \mathrm{C}\right)^{\mathrm{b}}\end{array}$ & $\begin{array}{l}\mathrm{E}^{\prime} \\
(\mathrm{MPa})^{\mathrm{b}}\end{array}$ & $\begin{array}{l}\nu \times 10^{-3} \\
(\mathrm{~mol} / \\
\left.\mathrm{cm}^{3}\right)^{\mathrm{b}}\end{array}$ \\
\hline- & 524.2 & 64.9 & 105.2 & 104.9 & 2889 & 3.24 \\
\hline $\begin{array}{c}\mathrm{C}_{4} \mathrm{MImCl} \\
(0.2)\end{array}$ & 516.6 & 64.4 & 104.2 & 106.8 & 2840 & 3.32 \\
$\begin{array}{c}\mathrm{C}_{4} \mathrm{MImCl} \\
(1.0)\end{array}$ & 499.3 & 59.7 & 101.6 & 107.1 & 2005 & 2.23 \\
$\begin{array}{c}\mathrm{C}_{4} \mathrm{MImCl} \\
(4.0)\end{array}$ & 357.4 & 54.7 & 99.6 & 98.6 & 2026 & 2.35 \\
$\begin{array}{c}\mathrm{C}_{4} \mathrm{MImNTf} \\
(1.0)\end{array}$ & 462.0 & 57.2 & 101.2 & 104.2 & 2906 & 3.09 \\
$\begin{array}{c}\mathrm{C}_{4} \mathrm{MImCl} \\
(4.0)^{\mathrm{c}}\end{array}$ & - & 124.5 & - & - & - & - \\
\hline
\end{tabular}

${ }^{\mathrm{a}} \Delta \mathrm{H}_{\mathrm{T}}, \mathrm{T}_{\text {onset }}$ and $\mathrm{T}_{\max }$ from DSC.

b $\mathrm{T}_{\mathrm{g}}, \mathrm{E}^{\prime}$ and $\nu$ from DMA.

c Composition without TETA.

$\mathrm{X}(\%)=\frac{\mathrm{R}_{0}-\mathrm{R}_{\mathrm{t}}}{\mathrm{R}_{0}} \times 100$

where $R_{0}$ is the ratio of the areas of the $915 \mathrm{~cm}^{-1}$ and $1183 \mathrm{~cm}^{-1}$ bands for the freshly mixed composition, and $\mathrm{R}_{\mathrm{t}}$ is the same ratio at a particular reaction time $t$, or after post-curing.

Thermogravimetric analysis (TGA) was performed using a TGA Q50 from TA Instruments in the temperature range of $25-940{ }^{\circ} \mathrm{C}$, at a heating rate of $20{ }^{\circ} \mathrm{C} / \mathrm{min}$, to evaluate degradation temperatures of some IL. Differential scanning calorimetry (DSC) was performed in a DSC Q20 from TA Instruments in the temperature range of $25-250{ }^{\circ} \mathrm{C}$ at a heating rate of $10{ }^{\circ} \mathrm{C} / \mathrm{min}$, for freshly prepared neat epoxy and for epoxy compositions with IL, to evaluate onset temperature, maximum curing rate temperature and total heat of reaction $\left(\Delta \mathrm{H}_{\mathrm{T}}\right.$, from the integration of the exothermic peak). ${ }^{1} \mathrm{H}$ NMR spectra of $\mathbf{C}_{4} \mathbf{M I m C l}$ and $\mathbf{C}_{4} \mathbf{M I m C l}+$ TETA were recorded in DMSO- $d_{6}$ on a Bruker $(400 \mathrm{MHz})$ equipment at ambient temperature. The chemical shifts are given in parts per million $(\mathrm{ppm})$ and referenced to the residual solvent signal of DMSO- $d_{6}(2.50)$. Dynamic-mechanical analysis (DMA) was carried out on prismatic specimens $(40.0 \times 12.7 \times 3.0 \mathrm{~mm})$ under three-point bending using a DMA 2980 from TA Instruments at a frequency of $1.0 \mathrm{~Hz}$, from 30 to 200 ${ }^{\circ} \mathrm{C}$. The crosslink density ( $v$ ) was estimated based on storage modulus in the rubbery state, ' $_{\mathrm{R}}$, using Eq. (2):

$\nu=\frac{E_{R}^{\prime}}{3 R T_{R}}$

where $R$ is the universal gas constant $(8.314 \mathrm{~J} / \mathrm{mol} . \mathrm{K})$ and $T_{R}$ is the absolute temperature $50 \mathrm{~K}$ above $\mathrm{T}_{\mathrm{g}}$. The calculated $\nu$ values were only used for comparison purposes since Eq. (2) is intended for less crosslinked polymers like rubbers [28].

The unnotched Izod impact test was performed with $70.0 \times 12.7 \times$ $3.0 \mathrm{~mm}$ specimens according to ASTM D4812 in a Ceast Impactor II equipment with a $2.75 \mathrm{~J}$ pendulum. Three-point bending tests were performed in prismatic $70.0 \times 12.7 \times 3.0 \mathrm{~mm}$ specimens, applying a span of $48 \mathrm{~mm}$ and a displacement rate of $1.35 \mathrm{~mm} / \mathrm{min}$ in accordance with ASTM D790. Tensile tests were performed with $80.0 \times 10.0 \times 4.0$ $\mathrm{mm}$ specimens at $2.0 \mathrm{~mm} / \mathrm{min}$ based on ASTM D638.

The single-edge-notch bending (SENB) fracture toughness test was carried out using $75.0 \times 10.0 \times 5.0 \mathrm{~mm}$ specimens for the calculation of $\mathrm{K}_{\mathrm{IC}}$ (stress intensity factor) and $\mathrm{G}_{\mathrm{IC}}$ (critical strain energy release rate), according to ASTM D5045. The specimens were notched with a Ceast NotchVis machine and a pre-crack was produced at the notch tip by sliding a razor blade. The test was performed at a crosshead speed of 1 

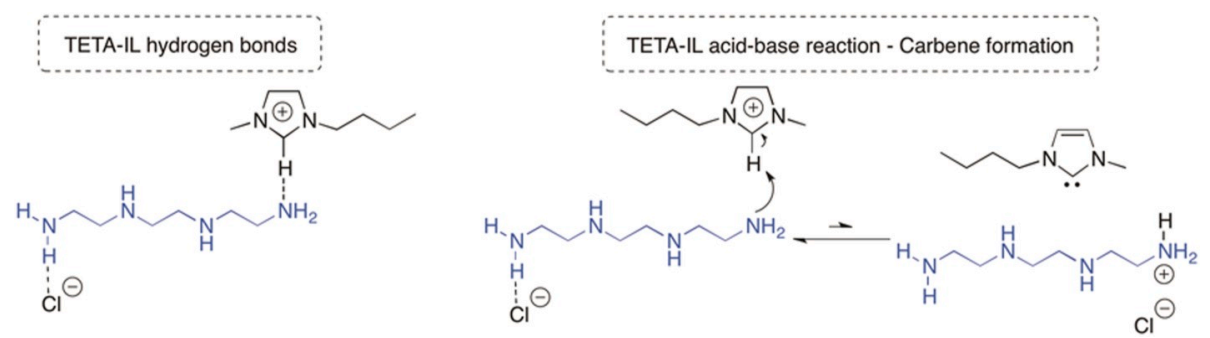

Fig. 5. Hydrogen bond between TETA and IL, and $N$-heterocyclic carbene formation.

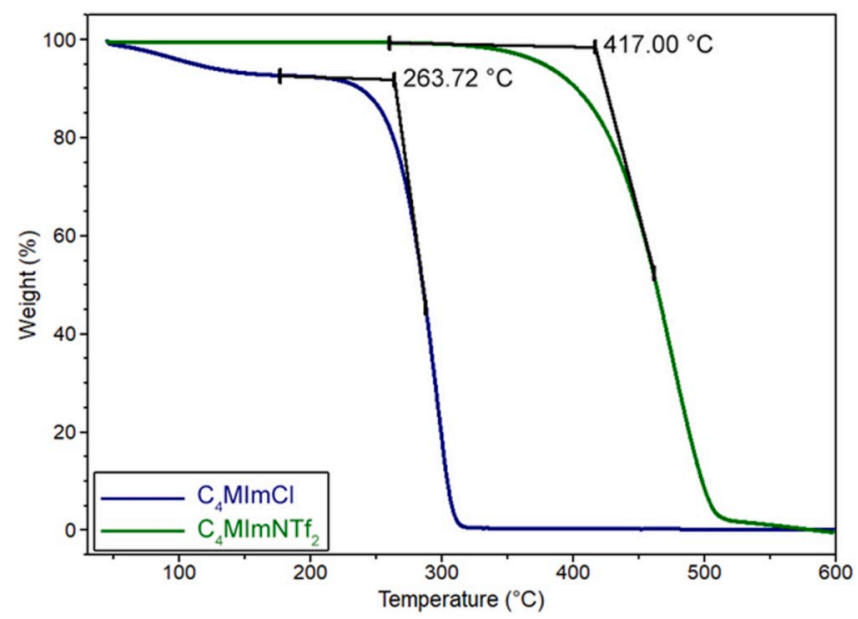

Fig. 6. TGA curves for the IL $\mathrm{C}_{4} \mathrm{MImCl}$ and $\mathrm{C}_{4} \mathrm{MImNTf}_{2}$.

$\mathrm{mm} / \mathrm{min}$, observing the criteria established in the standard to ensure a state of plane strain at the crack tip. Fracture toughness, flexural and tensile tests were performed in an Instron Universal Testing Machine model 3382 with a $5.0 \mathrm{kN}$ load cell. The crack surface of SENB specimens was observed via polarized optical microscopy with an Axioscope A1 equipment and scanning electron microscopy with a Phenom ProX Desktop equipment at an acceleration voltage of $10 \mathrm{kV} \mathrm{A}$.

For each mechanical test, 5-6 specimens were tested. The results were submitted to one-way statistical analysis of variance (ANOVA), with significance level of 5\%, followed by analysis between each pair of groups with the Fisher Least Significant Difference (LSD) method.

\section{Results and discussion}

Fig. 3(a) shows the FTIR transmission spectrum of freshly mixed DGEBA/TETA and Fig. 3(b) the spectrum obtained after post-curing. An epoxy group conversion of $97 \%$ was calculated after post-curing. In Fig. 3(c), greater attenuation of the $915 \mathrm{~cm}^{-1}$ band is noticed after postcuring for the resin with $4.0 \mathrm{phr}$ of $\mathbf{C}_{4} \mathbf{M I m C l}$, indicating higher conversion degree of the epoxy groups. Nevertheless, this does not necessarily imply greater crosslink density, as will be discussed later.

Fig. 4 shows the DSC results for freshly mixed DGEBA/TETA, DGEBA/TETA with different $\mathrm{C}_{4} \mathrm{MImCl}$ contents, DGEBA/TETA with 1.0 phr $\mathrm{C}_{4}$ MImNTf $_{2}$ and DGEBA with $4.0 \mathrm{phr} \mathrm{C}_{4} \mathrm{MImCl}$. For all compositions with TETA, there is a single, strong, exothermic peak, with an onset temperature around $60{ }^{\circ} \mathrm{C}$ (see Table 2), due to the DGEBA curing.

Differently, the DGEBA/ $\mathbf{C}_{4} \mathbf{M I m C l}$ composition without TETA showed two well-defined exothermic events, indicating the occurrence of reactions at different temperatures. The initial weak exothermic peak, with an onset temperature of $124.5^{\circ} \mathrm{C}$, can be attributed to the IL and ILDGEBA reactions identified by Binks et al. and Liebner et al. (Fig. 2) [15, 29], although not all of them were necessarily present. The subsequent higher energy peak can be predominantly ascribed to DGEBA curing, as well as IL and IL-DGEBA reactions. This calorimetric profile was also observed by Rahmathullah et al. [30], Soares et al. [31], and Mąka and Spychaj [32] for DGEBA cured with dicyanamide anion-based IL, $N$, $N^{\prime}$-dioctadecylimidazolium iodide and 1-ethyl-3-methylimidazolium chloride, respectively.

As shown in Table 2, there is a reduction in curing onset temperature with the addition of IL, together with a decrease in temperature at maximum curing rate, which suggests an IL-effect. This is most likely related to one or a combination of the mechanisms depicted in Fig. 2, and the $N$-heterocyclic carbene mechanism (ii) may have been promoted through an acid-base reaction between TETA and IL (Fig. 5).

Furthermore, even a small amount of IL attenuates the total energy of reaction $\left(\Delta \mathrm{H}_{\mathrm{T}}\right)$. This was also observed by Soares et al. [31] when DGEBA was cured with 4,4'-methylene-bis(3-chloro-2,6-diethylaniline) (MCDEA) in the presence of IL. The decrease in $\Delta \mathrm{H}_{\mathrm{T}}$ was attributed to the formation of hydrogen bonds between IL and TETA, lowering reactivity of the curing agent with a detrimental effect on its reaction with DGEBA. This hydrogen bond formation is represented in Fig. 5, which was studied by ${ }^{1} \mathrm{H}$ NMR spectroscopy. The spectra of $\mathrm{C}_{4} \mathrm{MImCl}$, and $\mathrm{C}_{4} \mathbf{M I m C l}+$ TETA (Fig. S11) confirmed such interaction, that is, when
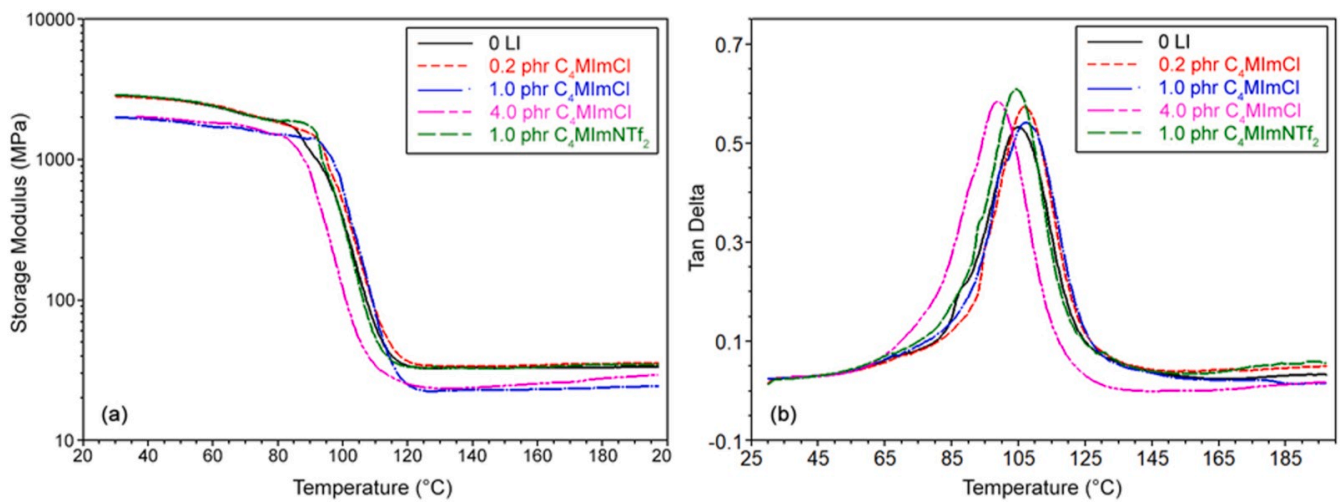

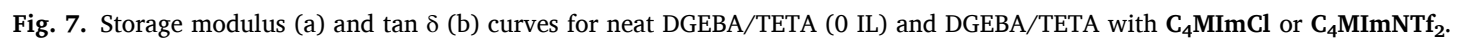




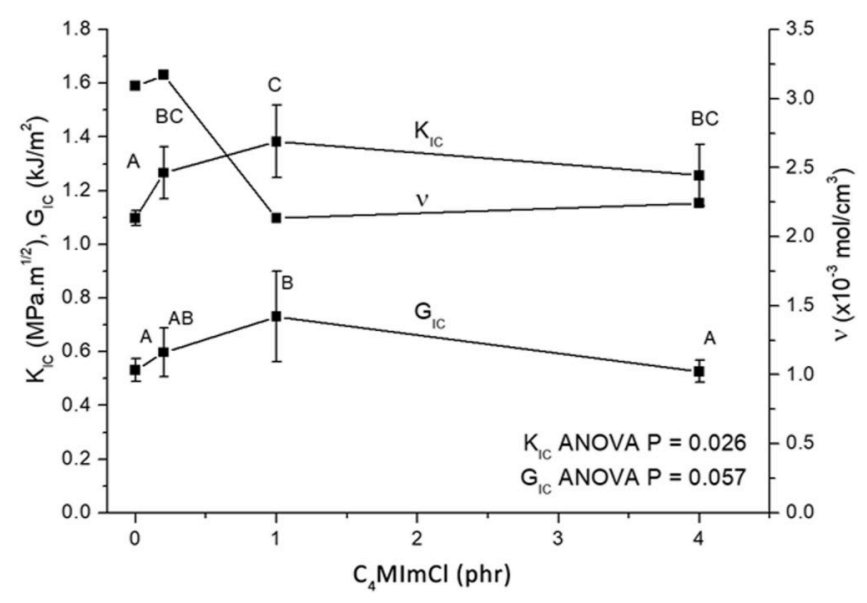

Fig. 8. $\mathrm{K}_{\mathrm{IC}}, \mathrm{G}_{\mathrm{IC}}$ and crosslink density results for different $\mathbf{C}_{\mathbf{4}} \mathbf{M I m C l}$ contents in DGEBA/TETA-based compositions (the same letter in a curve indicates no statistical difference between samples).

Table 3

Tensile, flexural and impact properties of DGEBA/TETA-based compositions with different contents of $\mathbf{C}_{4} \mathbf{M I m C l}$ and $\mathbf{C}_{4} \mathbf{M I m N T f}_{2}$.

\begin{tabular}{clllll}
\hline IL (phr) & $\begin{array}{l}\text { Tensile } \\
\text { strength } \\
(\mathrm{MPa})\end{array}$ & $\begin{array}{l}\text { Young } \\
\text { modulus } \\
(\mathrm{MPa})\end{array}$ & $\begin{array}{l}\text { Flexural } \\
\text { strength } \\
(\mathrm{MPa})\end{array}$ & $\begin{array}{l}\text { Flexural } \\
\text { modulus } \\
(\mathrm{MPa})\end{array}$ & $\begin{array}{l}\text { Impact } \\
\text { strength } \\
\left(\mathrm{kJ} / \mathrm{m}^{2}\right)\end{array}$ \\
\hline ANOVA P $^{\mathrm{a}}$ & 0.010 & 0.135 & 0.028 & 0.134 & 0.126 \\
\hline $\mathrm{Neat}^{\mathrm{b}}$ & $64.37 \pm$ & $1045 \pm 97$ & $112.49 \pm$ & $2858 \pm 70$ & $26.50 \pm$ \\
& $1.27^{\mathrm{BC}}$ & $\mathrm{AB}$ & $2.54^{\mathrm{A}}$ & $\mathrm{AB}$ & $5.95^{\mathrm{A}}$ \\
$\mathrm{C}_{4} \mathrm{MImCl}$ & $61.38 \pm$ & $1000 \pm$ & $119.70 \pm$ & $2677 \pm$ & $37.28 \pm$ \\
$(0.2)^{\mathrm{b}}$ & $2.37^{\mathrm{AB}}$ & $25^{\mathrm{A}}$ & $7.79^{\mathrm{B}}$ & $71^{\mathrm{A}}$ & $7.83^{\mathrm{B}}$ \\
$\mathrm{C}_{4} \mathrm{MImCl}$ & $69.66 \pm$ & $1140 \pm$ & $112.48 \pm$ & $2859 \pm$ & $37.15 \pm$ \\
$(1.0)^{\mathrm{b}}$ & $1.36^{\mathrm{C}}$ & $12^{\mathrm{B}}$ & $4.20^{\mathrm{A}}$ & $176^{\mathrm{B}}$ & $10.83^{\mathrm{B}}$ \\
$\mathrm{C}_{4} \mathrm{MImCl}$ & $61.30 \pm$ & $1014 \pm$ & $107.84 \pm$ & $2856 \pm$ & $27.91 \pm$ \\
$(4.0)^{\mathrm{b}}$ & $9.14^{\mathrm{AB}}$ & $107^{\mathrm{A}}$ & $3.75^{\mathrm{A}}$ & $193^{\mathrm{B}}$ & $8.81^{\mathrm{AB}}$ \\
$\mathrm{C}_{4} \mathrm{MImNTf}_{2}$ & $56.51 \pm$ & $914 \pm 56^{\mathrm{A}}$ & $115.37 \pm$ & $2923 \pm$ & $29.67 \pm$ \\
$(1.0)^{\mathrm{b}}$ & $6.13^{\mathrm{A}}$ & & $1.19^{\mathrm{AB}}$ & $80^{\mathrm{B}}$ & $3.95^{\mathrm{AB}}$ \\
\hline
\end{tabular}

${ }^{\text {a }}$ Values lower than 0.05 mean that there is a statistical difference in the property in relation to the DGEBA-TETA system.

b Different capital letters indicate statistically different groups from the Fisher LSD analysis.

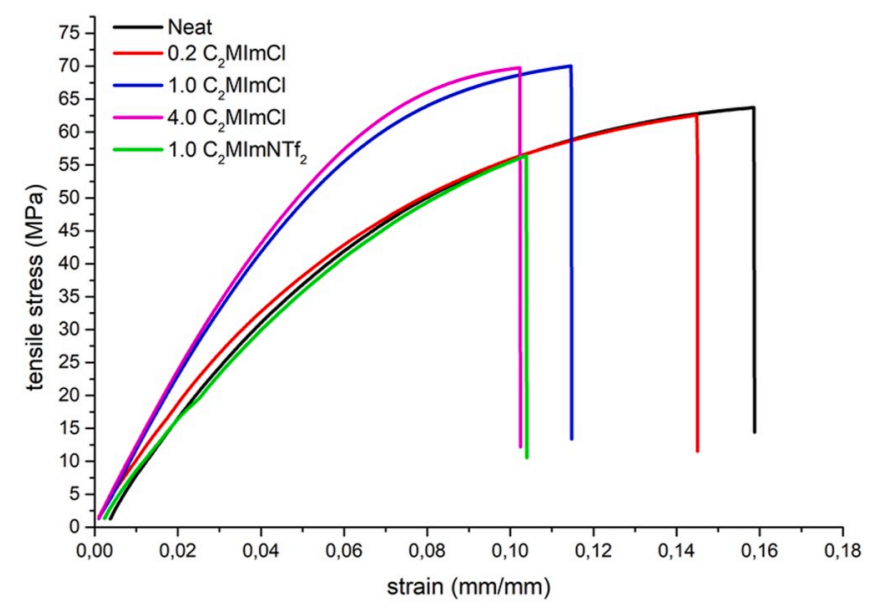

Fig. 9. Representative stress $v s$ strain tensile curves for epoxy compositions with $\mathbf{C}_{4} \mathbf{M I m C l}$ or $\mathbf{C}_{4} \mathbf{M I m N T f} \mathbf{f}_{2}$, and for neat epoxy.

$\mathrm{C}_{4} \mathrm{MImCl}$ was in the presence of TETA, the peaks related to its imidazolium ring hydrogens (C2-H, C4-H, C5-H) shifted. For the most acidic hydrogen of the imidazolium ring $(\mathrm{C} 2-\mathrm{H})$, the largest displacement was
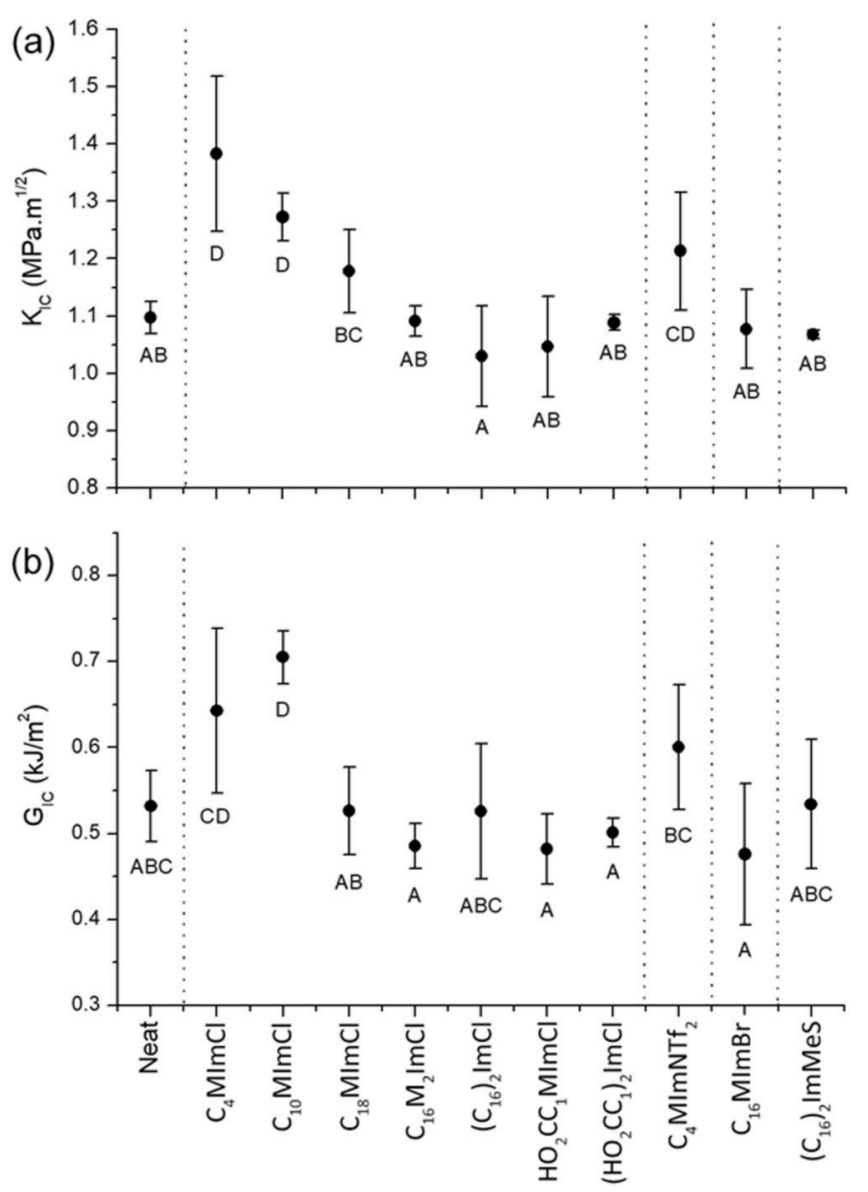

Fig. 10. $\mathrm{K}_{\mathrm{IC}}$ (a) and $\mathrm{G}_{\mathrm{IC}}$ (b) results for $1.0 \mathrm{phr}$ of various imidazolium IL in the DGEBA/TETA-based compositions (the same letter indicates no statistical difference between samples).

observed, shifting from $9.57 \mathrm{ppm}$ to $9.46 \mathrm{ppm}$. Thus, it is reasonable to say that strength of the hydrogen bond is IL-dependent.

The stronger acidity of the $\mathrm{C} 2$-proton in $\mathrm{C}_{4} \mathbf{M I m C l}$, compared to $\mathrm{C}_{4}$ MImNTf $_{2}$, implies in a stronger TETA-IL hydrogen bond interaction, which could explain the lower crosslink densities in the $1.0 \mathrm{phr}$ and 4.0 phr of $\mathbf{C}_{4} \mathbf{M I m C l}$ samples, despite the higher reactivity of $\mathbf{C}_{4} \mathbf{M I m C l}$, based on its lower degradation temperature from the TG results shown in Fig. 6 [14].

Guo et al. [16] identified an increase in activation energy with IL addition at lower temperatures, and an opposite behavior above $100^{\circ} \mathrm{C}$. Even so, a slight exothermic shift above $175^{\circ} \mathrm{C}$ is seen for samples with greater $\mathbf{C}_{4} \mathbf{M I m C l}$ content, especially for the $4.0 \mathrm{phr}$ of $\mathbf{C}_{4} \mathbf{M I m C l}$, probably due to the IL reaction with the remaining epoxy groups, or by its plasticizing effect, promoting mobility for final curing reactions. This reaction could occur at a post-curing stage at higher temperatures, eliminating oxirane groups, which can partly justify the previous FTIR results.

Storage modulus and tan $\delta$ curves are shown in Fig. 7(a)-(b). For compositions with higher $\mathrm{C}_{4} \mathrm{MImCl}$ content, i.e. $1.0-4.0 \mathrm{phr}$, there is a pronounced decrease in E' at room temperature suggesting a softening effect of the additive that is likely to be related to a reduction in crosslink density (see $v$ values shown in Table 2). Besides the previously mentioned role of the TETA-IL interactions (Fig. 5), IL-promoted DGEBA curing (Fig. 2) would produce branches through mechanisms (i) and (ii), and disturb crosslinking formation, producing a less rigid chemical structure. This was named by Hsu et al. [33] as nanostructured ether crosslinked domain. Except for the composition with $4.0 \mathrm{phr}$ of $\mathbf{C}_{4} \mathbf{M I m C l}$, where excess IL yielded a plasticizing effect [31], no 


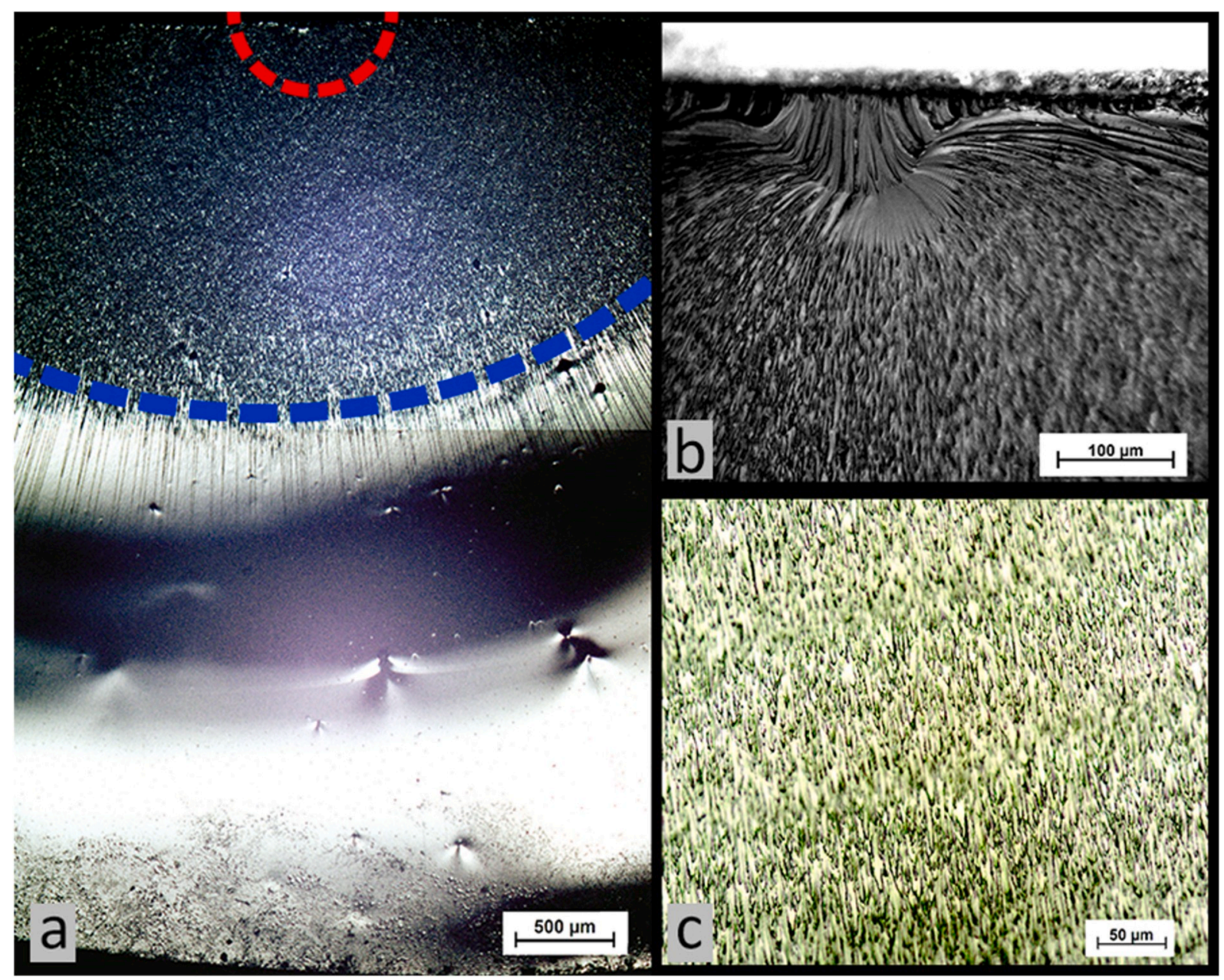

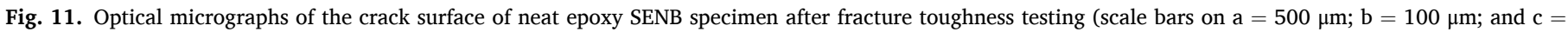
$50 \mu \mathrm{m})$.
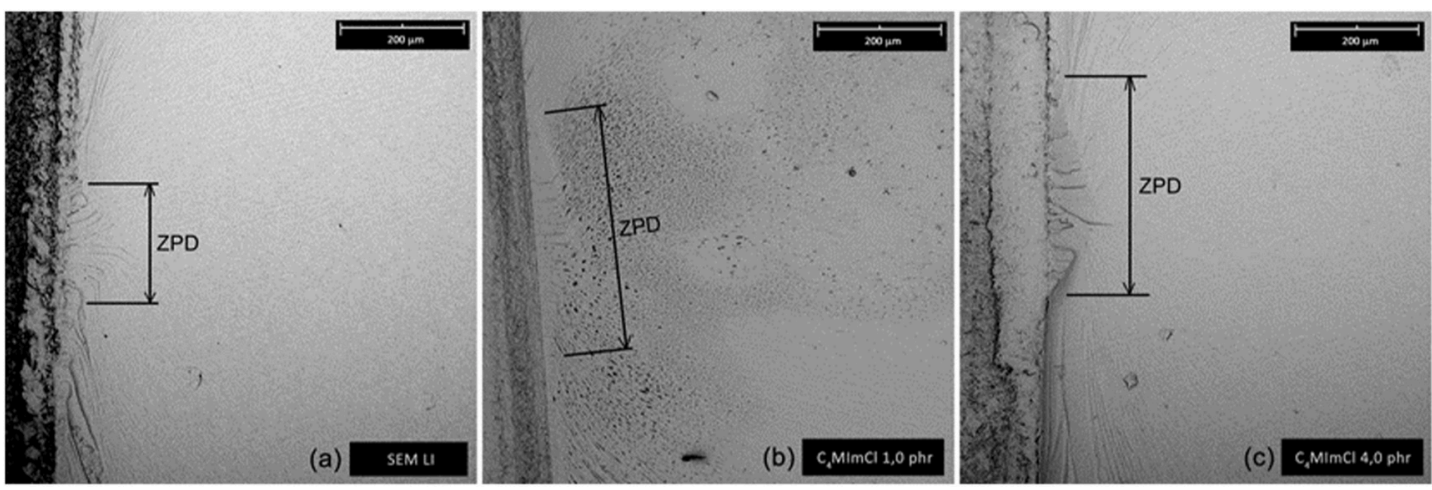

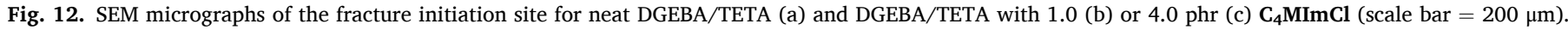

significant changes in $\mathrm{T}_{\mathrm{g}}$ of epoxy occurred.

Fig. 8 shows the $\mathrm{K}_{\mathrm{IC}}$ and $\mathrm{G}_{\mathrm{IC}}$ results along with the crosslink density results (from DMA) and an almost inverse correlation between them is apparent. In addition, there is a statistically significant increase in $\mathrm{K}_{\mathrm{IC}}$ as the $\mathbf{C}_{4} \mathbf{M I m C l}$ content in the resin increased up to $1.0 \mathrm{phr}$, and $\mathrm{K}_{\mathrm{IC}}$ increased $25.4 \%$, from 1.10 to $1.38 \mathrm{MPa} \mathrm{m}^{-1 / 2}$, compared to the neat epoxy. $\mathrm{G}_{\mathrm{IC}}$ increased even more (37.6\%), from 0.532 to $0.732 \mathrm{~kJ} / \mathrm{m}^{2}$, for the same IL, but this increase was not supported by the statistical analysis due to the greater deviation in results. These results suggest that the reduced crosslink density allowed a higher degree of chain mobility, increasing plastic deformation at the crack tip during crack propagation.

The results of tensile strength and modulus, flexural strength and modulus, and impact strength are shown in Table 3. These mechanical properties were evaluated to verify nay detrimental effect from the IL addition, especially considering its effect on crosslink density (Table 2). There's a trend for increased impact strength for the addition of 0.2 and $1.0 \mathrm{phr}$ of $\mathrm{C}_{4} \mathbf{M I m C l}$, but this difference is not statistically significant due to dispersion in results, which is expected for brittle materials. No significant changes were noticed in Young and flexural moduli, but $0.2 \mathrm{phr}$ of $\mathrm{C}_{4} \mathrm{MImCl}$ yielded a significant increase in flexural strength, while 1.0 
phr of the same IL resulted in an $8.2 \%$ increase in tensile strength.

Fig. 9 shows typical stress versus strain curves of epoxy compositions containing $\mathrm{C}_{4} \mathbf{M I m C l}$ or $\mathrm{C}_{4} \mathrm{MImNTf}_{2}$, and for neat epoxy. An increase in tensile strength and a decrease in strain at break occurred for higher $\mathrm{C}_{4} \mathrm{MImCl}$ content. This strain reduction can be justified by the increase in stiffness. Addition of $1.0 \mathrm{phr}$ of $\mathbf{C}_{4} \mathbf{M I m N T f}_{2}$ did not improve tensile strength, differently from Soares et al. [19], who reported higher strength for imidazolium and phosphonium based IL.

The previously mentioned reduced reactivity between DGEBA and TETA in the presence of IL (Fig. 5) could promote DGEBA homopolymerization through etherification. This may justify the improvement in tensile strength with a reduction in crosslink density observed with the addition of $1.0 \mathrm{phr}$ of $\mathbf{C}_{4} \mathbf{M I m C l}$. Such a change in reaction profile would yield an epoxy resin with longer distances between crosslinks, intensifying secondary interactions between crosslinked chains, such as inter-chain hydrogen bonds, dipolar interactions as well as entanglements [34]. These interactions could hinder chain movement when under stress at low temperatures.

Based on the optimum content of $\mathbf{C}_{4} \mathbf{M I m C l}$ for fracture toughening, compositions with the same content of other IL were produced. The $\mathrm{K}_{\mathrm{IC}}$ and $\mathrm{G}_{\mathrm{IC}}$ results for the various IL used in this work are shown in Fig. 10. In general, the best results were obtained with chloride anion IL, where $\mathbf{C}_{\mathbf{4}} \mathbf{M I m C l}$ produced the highest $\mathrm{K}_{\mathrm{IC}}$ values and $\mathbf{C}_{\mathbf{1 0}} \mathbf{M I m C l}$ the highest $\mathrm{G}_{\mathrm{IC}}$ values, indicating a trend for shorter $N$-alkyl chain-substituted imidazolium cations to produce tougher materials. Indeed, $\mathbf{C}_{4} \mathbf{M I m N T f}_{2}$ also yielded improved toughness, whereas the other IL were mostly similar to neat epoxy.

It is important to stress that different IL may show different optimal contents. Thus, effectiveness of the IL in reducing the crosslink density depends not only on reactivity itself, but also on its molar content, i.e. the number of reacting groups. In this study, the IL with the greater molar content (1:0.0214 for DGEBA/ $\left.\mathbf{C}_{4} \mathbf{M I m C l}\right)$ produced the best results. However, this does not mean that other IL would behave similarly and, in fact, $\mathbf{H O}_{2} \mathbf{C C}_{1} \mathbf{M I m C l}$, with almost the same content, resulted in lower $\mathrm{K}_{\mathrm{IC}}$. In the compositions with $\mathbf{H O}_{2} \mathbf{C C}_{1} \mathbf{M I m C l}$ or $\left(\mathrm{HO}_{2} \mathrm{CC}_{1}\right)_{2} \mathrm{ImCl}$, precipitation of agglomerates was observed after addition of the curing agent. This could be attributed to the acceleration of the resin cure in the presence of IL, or a direct reaction between IL and TETA. This adverse effect may justify their lower fracture toughness.

The flexural-fractured epoxy surfaces (Fig. 11) appeared similar to those described by Wu et al. [6]. Three different regions were identified from the crack initiation site (the red circle in Fig. 11), which were: (i) a very small mirrored and flat zone (Fig. 11(b)); (ii) a smooth zone, formed by arrays of parabolic marks, which can be seen inside the blue dashed circle in Fig. 11(a) and with higher magnification in Fig. 11(c); and (iii) a rough, three-dimensional zone that can be seen at the bottom of Fig. 11(a).

Fig. 12 shows SEM micrographs of fracture initiation zones in the SENB test for neat epoxy and specimens with 1.0 or 4.0 phr of $\mathbf{C}_{4} \mathbf{M I m C l}$. In all samples, a zone of plastic deformation (ZPD) is observed, with microcracks on both sides that lead to the fracture initiation region. The composition with $1.0 \mathrm{phr}$ of $\mathbf{C}_{\mathbf{4}} \mathbf{M I m C l}$ showed a broader ZPD compared to neat epoxy, possibly indicating greater absorption of energy, most likely due to its lower crosslink density. This material also exhibited microporosity in the region just ahead of the ZPD. And since this porosity was only observed in that region, it is expected to have been produced during fracture. The composition with $4.0 \mathrm{phr}$ of $\mathrm{C}_{4} \mathbf{M I m C l}$ presented a deeper ZPD, with greater plastic deformation and larger lateral microcracks, which could be related to the plasticizing effect of this IL at higher content.

\section{Conclusions}

The potential of imidazolium IL as liquid toughening agents for conventional low temperature TETA cured DGEBA epoxy resin was evaluated in terms of crosslink density and fracture toughness. Among the tested IL, $\mathbf{C}_{4} \mathbf{M I m C l}$ was identified with the highest potential. The IL reduced TETA reactivity and took part in the epoxy curing reactions, decreasing onset temperature, temperature at maximum curing rate, and total reaction energy between TETA and DGEBA. The highest fracture toughness was achieved with the addition of $1.0 \mathrm{phr} \mathrm{C}_{4} \mathbf{M I m C l}$, an increment of $25.4 \%$ in relation to neat epoxy (from 1.10 to $1.38 \mathrm{MPa}$ $\mathrm{m}^{-1 / 2}$ ), together with a reduction in crosslink density from $3.24 \times 10^{-3}$ to $2.23 \times 10^{-3} \mathrm{~mol} / \mathrm{cm}^{3}$. Furthermore, no significant losses were noticed in other properties, including $\mathrm{T}_{\mathrm{g}}$, which increased just slightly (from 104.9 to $107.1^{\circ} \mathrm{C}$ ). On the contrary, addition of $\mathbf{C}_{4} \mathbf{M I m C l}$ resulted in a reasonable increase in tensile strength (from 64 to $69 \mathrm{MPa}$ ). This increase in tensile strength with crosslink reduction was attributed to secondary bonding formation. As such, $\mathrm{C}_{4} \mathbf{M I m C l}$ was considered a promising toughening agent for the DGEBA-TETA epoxy system.

\section{Data availability}

Supporting information with NMR and FTIR data is available.

\section{Declaration of competing interest}

The authors declare that they have no known competing financial interests or personal relationships that could have appeared to influence the work reported in this paper.

\section{CRediT authorship contribution statement}

E. Fonseca: Conceptualization, Data curation, Formal analysis, Investigation, Methodology, Writing - original draft, Writing - review \& editing. V. Demétrio da Silva: Investigation, Methodology, Writing review \& editing. J.S. Klitzke: Methodology, Investigation. H.S. Schrekker: Conceptualization, Writing - review \& editing, Supervision. S.C. Amico: Conceptualization, Writing - review \& editing, Supervision, Project administration.

\section{Acknowledgements}

This study was partly financed by the Coordenação de Aperfeiçoamento de Pessoal de Nivel Superior - Brasil (CAPES), Finance Code 001. The authors thank Conselho Nacional de Desenvolvimento Científico e Tecnológico (CNPq) - Brasil for research productivity fellowships, and the CAPES/STINT project.

\section{Appendix A. Supplementary data}

Supplementary data to this article can be found online at https://doi. org/10.1016/j.polymertesting.2020.106556.

\section{References}

[1] J. Wang, X. Zhang, L. Jiang, J. Qiao, Advances in toughened polymer materials by structured rubber particles, Prog. Polym. Sci. 98 (2019), 101160, https://doi.org/ 10.1016/j.progpolymsci.2019.101160.

[2] D. Gunwant, L.P. Sah, M.G.H. Zaidi, Fabrication and characterization of novel liquid rubber modified epoxies, Mater. Today Proc. 5 (2018) 24750-24759, https://doi.org/10.1016/j.matpr.2018.10.273.

[3] S. Gantayat, D. Rout, S.K. Swain, Carbon nanomaterial - reinforced epoxy Composites : a review, Polym. Plast. Technol. Eng. 57 (2018) 1-16, https://doi. org/10.1080/03602559.2017.1298802.

[4] C.M. Vu, L.H. Sinh, D.D. Nguyen, H.V. Thi, H.J. Choi, Simultaneous improvement of the fracture toughness and mechanical characteristics of amine-functionalized nano/micro glass fibril-reinforced epoxy resin, Polym. Test. 71 (2018) 200-208, https://doi.org/10.1016/j.polymertesting.2018.09.005.

[5] C.R. Picu, K.K. Krawczyk, Z. Wang, H. Pishvazadeh-Moghaddam, M. Sieberer, A. Lassnig, W. Kern, A. Hadar, D.M. Constantinescu, Toughening in nanosilicareinforced epoxy with tunable filler-matrix interface properties, Compos. Sci. Technol. 183 (2019), 107799, https://doi.org/10.1016/j. compscitech.2019.107799.

[6] T. Wu, Y. Liu, N. Li, G.W. Huang, C.B. Qu, H.M. Xiao, Cryogenic mechanical properties of epoxy resin toughened by hydroxyl-terminated polyurethane, Polym. Test. 74 (2019) 45-56, https://doi.org/10.1016/j.polymertesting.2018.11.048. 
[7] C. Uhlig, O. Kahle, O. Schäfer, D. Ewald, H. Oswaldbauer, J. Bauer, M. Bauer, Blends of tri-block copolymers and addition curing resins: influence of block copolymer-resin compatibility on toughness and matrix properties on toughenability, React. Funct. Polym. 142 (2019) 159-182, https://doi.org/ 10.1016/j.reactfunctpolym.2019.06.012

[8] K.P. Unnikrishnan, E.T. Thachil, Toughening of epoxy resins, Des. Monomers Polym. 9 (2006) 129-152, https://doi.org/10.1163/156855506776382664.

[9] R.J. Varley, Toughening of epoxy resin systems using low-viscosity additives, Polym. Int. 53 (2004) 78-84, https://doi.org/10.1002/pi.1321.

[10] A. Vashchuk, A.M. Fainleib, O. Starostenko, D. Grande, Application of ionic liquids in thermosetting polymers: epoxy and cyanate ester resins, Express Polym. Lett. 12 (2018) 898-917, https://doi.org/10.3144/expresspolymlett.2018.77.

[11] Y. Kitazawa, K. Ueno, M. Watanabe, Advanced materials based on polymers and ionic liquids, Chem. Rec. 18 (2018) 391-409, https://doi.org/10.1002/ tcr.201700041.

[12] C.M.L. Schrekker, Y.C.A. Sokolovicz, M.G. Raucci, B.S. Selukar, J.S. Klitzke, W. Lopes, C.A.M. Leal, I.O.P. De Souza, G.B. Galland, J.H.Z. Dos Santos, R. S. Mauler, M. Kol, S. Dagorne, L. Ambrosio, M.L. Teixeira, J. Morais, R. Landers, A. M. Fuentefria, H.S. Schrekker, Multitask imidazolium salt additives for innovative poly(L-lactide) biomaterials: morphology control, Candida spp. biofilm inhibition, human mesenchymal stem cell biocompatibility, and skin tolerance, ACS Appl. Mater. Interfaces 8 (2016) 21163-21176, https://doi.org/10.1021/ acsami.6b06005.

[13] K. Kowalczyk, T. Spychaj, Ionic liquids as convenient latent hardeners of epoxy resins, Polimery 48 (2003) 833-835, https://doi.org/10.14314/ polimery.2003.833.

[14] H. Maka, T. Spychaj, R. Pilawka, Epoxy resin/ionic liquid systems: the influence of imidazolium cation size and anion type on reactivity and thermomechanical properties, Ind. Eng. Chem. Res. 51 (2012) 5197-5206, https://doi.org/10.1021/ ie202321j.

[15] F.C. Binks, G. Cavalli, M. Henningsen, B.J. Howlin, I. Hamerton, Investigating the mechanism through which ionic liquids initiate the polymerisation of epoxy resins, Polymer 139 (2018) 163-176, https://doi.org/10.1016/j.polymer.2018.01.087.

[16] B. Guo, J. Wan, Y. Lei, D. Jia, Curing behaviour of epoxy resin/graphite composites containing ionic liquid, J. Phys. D Appl. Phys. 42 (2009), 145307, https://doi.org/ 10.1088/0022-3727/42/14/145307.

[17] B.G. Soares, S. Livi, J. Duchet-Rumeau, J.F. Gerard, Preparation of epoxy/MCDEA networks modified with ionic liquids, Polymer 53 (2012) 60-66, https://doi.org/ 10.1016/j.polymer.2011.11.043.

[18] Y.Q. Shi, T. Fu, Y.J. Xu, D.F. Li, X.L. Wang, Y.Z. Wang, Novel phosphoruscontaining halogen-free ionic liquid toward fire safety epoxy resin with wellbalanced comprehensive performance, Chem. Eng. J. 354 (2018) 208-219, https:// doi.org/10.1016/j.cej.2018.08.023.

[19] B.G. Soares, A.A. Silva, S. Livi, J. Duchet-Rumeau, J.F. Gerard, New Epoxy/ Jeffamine networks modified with ionic liquids, J. Appl. Polym. Sci. 131 (2014), 39834, https://doi.org/10.1002/app.39834.

[20] T.K.L. Nguyen, S. Livi, B.G. Soares, S. Pruvost, J. Duchet-Rumeau, J.F. Gérard, Ionic liquids: a new route for the design of epoxy networks, ACS Sustain. Chem. Eng. 4 (2016) 481-490, https://doi.org/10.1021/acssuschemeng.5b00953.

[21] F.I. Ziembowicz, C.R. Bender, C.P. Frizzo, M.A.P. Martins, T.D. De Souza, C. L. Kloster, I.T. Santos Garcia, M.A. Villetti, Thermodynamic insights into the binding of mono- and dicationic imidazolium surfactant ionic liquids with methylcellulose in the diluted regime, J. Phys. Chem. B 121 (2017) 8385-8398, https://doi.org/10.1021/acs.jpcb.7b03525.

[22] Z. Huang, Y. Wang, N. Zhang, L. Zhang, D.J. Darensbourg, One-pot synthesis of ion-containing CO2-based polycarbonates using protic ionic liquids as chain transfer agents, Macromolecules 51 (2018) 9122-9130, https://doi.org/10.1021/ acs.macromol.8b01834.

[23] R. Rohini, C.K. Lee, J.T. Lu, I.J.B. Lin, Symmetrical 1, 3-dialkylimidazolium based ionic liquid crystals, J. Chin. Chem. Soc. 60 (2013) 745-754, https://doi.org/ 10.1002/jccs.201200598.

[24] A. Toppino, M.E. Bova, S.G. Crich, D. Alberti, E. Diana, A. Barge, S. Aime, P. Venturello, A. Deagostino, A carborane-derivative "click" reaction under heterogeneous conditions for the synthesis of a promising lipophilic MRI/GdBNCT agent, Chem. Eur J. 19 (2013) 721-728, https://doi.org/10.1002/ chem. 201201634.

[25] A. Chakraborty, S. Debnath, T. Ghosh, D.K. Maiti, S. Majumdar, An efficient strategy for N-alkylation of benzimidazoles/imidazoles in SDS-aqueous basic medium and N-alkylation induced ring opening of benzimidazoles, Tetrahedron 74 (2018) 5932-5941, https://doi.org/10.1016/j.tet.2018.08.029.

[26] H.S. Schrekker, D.O. Silva, M.A. Gelesky, M.P. Stracke, C.M.L. Schrekker, R. S. Gonçalves, J. Dupont, Preparation, cation-anion interactions and physicochemical properties of ether-functionalized imidazolium ionic liquids, J. Braz. Chem. Soc. 19 (2008) 426-433, https://doi.org/10.1590/S010350532008000300009.

[27] A.A. Silva, S. Livi, D.B. Netto, B.G. Soares, J. Duchet, J.F. Gérard, New epoxy systems based on ionic liquid, Polymer 54 (2013) 2123-2129, https://doi.org/ 10.1016/j.polymer.2013.02.021.

[28] Q. Jin, J.M. Misasi, J.S. Wiggins, S.E. Morgan, Simultaneous reinforcement and toughness improvement in an aromatic epoxy network with an aliphatic hyperbranched epoxy modifier, Polymer 73 (2015) 174-182, https://doi.org/ 10.1016/j.polymer.2015.07.031.

[29] F. Liebner, I. Patel, G. Ebner, E. Becker, M. Horix, A. Potthast, T. Rosenau, Thermal aging of 1-alkyl-3-methylimidazolium ionic liquids and its effect on dissolved cellulose, Holzforschung 64 (2010) 161-166, https://doi.org/10.1515/ HF.2010.033.

[30] M.A.M. Rahmathullah, A. Jeyarajasingam, B. Merritt, M. VanLandingham, S. H. McKnight, G.R. Palmese, Room temperature ionic liquids as thermally latent initiators for polymerization of epoxy resins, Macromolecules 42 (2009) 3219-3221.

[31] B.G. Soares, S. Livi, J. Duchet-Rumeau, J.F. Gerard, Synthesis and characterization of epoxy/MCDEA networks modified with imidazolium-based ionic liquids, Macromol. Mater. Eng. 296 (2011) 826-834, https://doi.org/10.1002/ mame.201000388.

[32] H. Maka, T. Spychaj, Epoxy resin crosslinked with conventional and deep eutectic ionic liquids, Polimery 57 (2012) 456-462, https://doi.org/10.14314/ polimery.2012.456.

[33] Y.G. Hsu, K.H. Lin, T.Y. Lin, Y.L. Fang, S.C. Chen, Y.C. Sung, Properties of epoxyamine networks containing nanostructured ether-crosslinked domains, Mater. Chem. Phys. 132 (2012) 688-702, https://doi.org/10.1016/j. matchemphys.2011.11.087.

[34] C.L. Sherman, R.C. Zeigler, N.E. Verghese, M.J. Marks, Structure-property relationships of controlled epoxy networks with quantified levels of excess epoxy etherification, Polymer 49 (2008) 1164-1172, https://doi.org/10.1016/j. polymer.2008.01.037. 